How to Cite

Widiastini, N. P. D., Candiasa, I. M., \& Suharta, I. (2018). Development of interactive multimedia learning surface area of solid geometry. International Journal of Physics \& Mathematics, 1(1), 1-7. https://doi.org/10.31295/ijpm.v1n1.38

\title{
Development of Interactive Multimedia Learning Surface Area of Solid Geometry
}

\author{
Ni Putu Dina Widiastini \\ University of Ganesha Education, Singaraja, Indonesia \\ Corresponding author email: dinawidiastini@gmail.com \\ I Made Candiasa \\ University of Ganesha Education, Singaraja, Indonesia \\ IGP Suharta \\ University of Ganesha Education, Singaraja, Indonesia
}

\begin{abstract}
This research was aimed to (1) create the interactive multimedia learning design surface area of solid geometry (cube, cuboid, prism, pyramid); (2) produce the multimedia by using GeoGebra as a media of exploration, Camtasia Studio as an application for editing sound and video, Lectora Inspire as an application for making layout and quiz; (3) know the effectiveness of interactive multimedia learning surface area of solid geometry (cube, cuboid, prism, pyramid). The 4-D model research and development designed was applied in this study through four stages, such as for define, design, develop, and disseminate stages with adjusted subjects in each stage. This research used quantitative and qualitative data analysis. The result of this research showed that the development of multimedia learning can be accepted as learning media with the mean score from the expert of multimedia devices was 27 with good criteria, and the mean score from the expert of material was 29 with good criteria. The development of multimedia was also fulfill the usage criteria with good criteria. Based on the result of the research that had been done from dissemination stages, the implementation was limited, the interactive multimedia learning surface area of solid geometry was effective, with the percentage of classical completeness of students by $80 \%$. Hence, both the teachers and students are encouraged to use multimedia learning developed as a supporter of computer-based learning so that the learning process is more varied.
\end{abstract}

Keywords---4-D, effectiveness, multimedia, surface area of solid geometry, usage.

\section{Introduction}

Technology and information have become an important part of globalization era. The technology has effect every aspect of human life including the education activities. Education is an activity that interaction between learners, educators and various sources of education (Sukmadinata, 2016). An educational system is influenced by a factor of curriculum and the educator. So, in the process of learning, an educator is required to be able to innovate in order to improve the quality of learning process and will improve the quality of education.

Mathematics learning needs to get serious attention at all levels of education including to junior high school. For the more effective learning of mathematics, we need to look for new innovation in the learning process, because students already consider that math lesson is a difficult lesson and identical with memorizing the formula. New innovations in learning mathematics should be more emphasis on exploration and investigation of mathematics. One of the innovations that can be done in learning mathematics is use multimedia.

Hofstetter (Suyanto, 2003) defines that multimedia is the use of computers to create or combine text, graphics, audio, motion pictures (video and animation) by combining links and tools that allow users to navigate, interact, create and communicate. The advantages of multimedia learning according to Newby (2000) are as follows.

ISSN 2632-9417

Received Jan 10, 2018 / Accepted Jun 20, 2018 / Published Jul 05, 2018 
a) Be realistic, learners can hear what the real events;

b) Motivate learners to improve their positive attitude;

c) Effective for all types of learning;

d) Interactive, multimedia can present information, feedback, and evaluation;

e) Consistent, procedures and every step can be done by all learners;

f) Controlled, can be used by different levels of learners' understanding;

g) Personal, every learner can control the learning according to the level of understanding;

h) Learning becomes more interesting;

i) Can be used in various types of learning.

Thus, mathematics learning becomes more interactive, and then the student involvement in the learning process becomes more optimal. From that case, the teacher as a learning designer can use multimedia to transferring information to students. Therefore, the learning process will be more meaningful. The use of multimedia learning in the learning process can also generate new desires and interests for students, student motivation. In addition, to improving student learning motivation, media utilization can also improve students' understanding of learning (Arsyad, 2010).

Based on the observation, the problems that were often encountered in a junior high school was a learning process that tends to be monotonous and less varied in the use of learning media, so the student involvement in learning process was not optimal. Based on one of mathematics teacher's interview, the problem that often found was the concentration of students in the learning process was less and the students tend to memorize the formula to solve the problem, which leads to less understanding of the concept of students especially in the lesson of geometry. This problem cannot be separated from the lack of multimedia learning facilities in schools, which causes teachers to only use the blackboard and the supporting books in learning, so that less interesting for students and caused students to be passive in learning.

Related to the condition, the researcher was interested to develop an interactive learning math for students especially Class VIII. This multimedia was expected to help improve the understanding of mathematical concepts, especially geometry material for the subject of the surface area of solid geometry.

\section{Research Methods}

This research was research and development. The development model used in this research and development was the 4-D, which consists of four stages, such as for define, design, develop, and disseminate stage. In this research produced an interactive multimedia learning surface area of solid geometry that has been evaluated by the experts and tested. Generally, the stages of development activities and the outcome of activities presented in table 1 .

Table 1

The stages of development activities and the outcome of activities

\begin{tabular}{|c|c|c|c|}
\hline Stage & & Description of Activities & Outcomes and Indicators of Achievement \\
\hline \multirow[t]{2}{*}{ Define } & a) & $\begin{array}{l}\text { Identify the problems } \\
\text { encountered. }\end{array}$ & $\begin{array}{l}\text { The identification of mathematics learning problems on } \\
\text { surface area of solid geometry materials. }\end{array}$ \\
\hline & b) & Analyze the curriculum & $\begin{array}{l}\text { Knowing the boundary surface area of solid geometry } \\
\text { material that will be developed. }\end{array}$ \\
\hline \multirow[t]{2}{*}{ Design } & a) & $\begin{array}{l}\text { Creating a design of } \\
\text { multimedia learning }\end{array}$ & $\begin{array}{l}\text { arranging a design of interactive multimedia learning } \\
\text { surface area of solid geometry }\end{array}$ \\
\hline & b) & $\begin{array}{l}\text { to Implementation, the design } \\
\text { of multimedia learning on the } \\
\text { surface area of solid geometry } \\
\text { materials use the software }\end{array}$ & $\begin{array}{l}\text { Produce an interactive multimedia learning surface } \\
\text { area of solid geometry }\end{array}$ \\
\hline Develop & $\begin{array}{l}\text { doin } \\
\text { revi }\end{array}$ & $\begin{array}{l}\text { ig product evaluation and } \\
\text { sions based on limited trials. }\end{array}$ & $\begin{array}{l}\text { Produced interactive multimedia learning surface area } \\
\text { of solid geometry that has been evaluated }\end{array}$ \\
\hline
\end{tabular}


Disseminate doing dissemination of multimedia to know the effectiveness
Produced an effective multimedia interactive learning surface area of solid geometry to improve students' mathematical understanding

Questionnaire of experts' Material validation, a questionnaire of experts' multimedia, teacher response questionnaire and student response questionnaire were the instruments used in this development. Indicators of assessment on the questionnaire of teacher and student responses used five scoring scales, those were; strongly agree (score 5), agree (score 4), distrust (score 3), disagree (score 2), strongly disagree (score 1). While the questionnaire validation of expert's material and questionnaire validation of experts multimedia using three scales, which is valid (score 3), quite valid (score 2), and not valid (score 1). The type of test used is an objective test in the form of multiple choice with the number of questions as 10 questions. All of the instruments used in the research had been tested in terms of content validity by two validators, namely, two lecturers from the Mathematics Education Department, Undiksha.

Data analysis technique used in this research was qualitative and quantitative data analysis technique. Qualitative data analysis technique used to manage data review of material experts, learning device experts, and student responses to multimedia learning. The results of this data were used as a guide or reference to evaluate the multimedia. Quantitative descriptive data analysis techniques were used to manage the feasibility questionnaires and student response questionnaires. The results of this data analysis then used to determine the feasibility, usage, and effectiveness of developed multimedia learning.

The feasibility of the multimedia learning developed in this study was determined based on the assessment of four experts, namely two mathematics teachers at SMP Negeri 2 Kediri as a material expert and two lecturers in Undiksha who have education, profession, and achievement in multimedia as a multimedia expert and provide his assessment through a questionnaire. The data that obtained from the feasibility test of multimedia learning by experts using questionnaires converted into several criteria that developed multimedia included in good or feasible criteria for $23,33<\bar{X}$, quate good criteria for $16,67<\bar{X} \leq 23,33$ and less criteria for $\bar{X} \leq 16,67$, with $\bar{X}$ mean of total score from experts.

The usage of developed multimedia learning in this study was measured based on the implementation of the media in the group of students on a limited trial. A limited trial was conducted on 10 students grade VIII of SMP Negeri 2 Kediri. Data on the usage test of learning multimedia obtained from the questionnaire of student responses and student interview to developed multimedia learning. The Multimedia that had been through the limited trial process and had been revised, then tested in one class for students of grade VIII in SMP Negeri 2 Kediri. These trials were conducted to obtain feasible and practical products, if there are still weaknesses and shortcomings then the multimedia will be improved so as to produce multimedia interactive learning surface area of solid geometry.

The effectiveness of the multimedia learning was measured by the students' learning mastery after using the developed multimedia learning. The effectiveness test was conducted at the disseminated stage. However, due to the limitation of time and the cost owned by researchers, this process was only done limited to students of class VIII SMP Negeri 2 Kediri. The implementation was done in different classes with the class trial at the development stage at SMP Negeri 2 Kediri. Furthermore, the dissemination of product development was doing in other classes and by other teachers in SMP Negeri 2 Kediri. At this stage, the learning was done in three meetings to determine the effectiveness of the multimedia that has been produced. Interactive multimedia learning surface area solid geometry can be said to be effective if student complete classically. The data categorized based on Minimum Exhaustiveness Criteria that applicable in grade VIII SMPN 2 Kediri to know the students' learning mastery. Student's mathematical completeness criteria can be seen in Table 2 below.

Tabel 2

Table of students mastery category

\begin{tabular}{lll}
\hline No. & Skor Siswa & Kategori \\
\hline 1 & Skor $\geq$ Minimum Exhaustiveness Criteria & Complete \\
2 & Skor $<$ Minimum Exhaustiveness Criteria & Not complete \\
\hline
\end{tabular}


The value of classical completeness can be analyzed with the following formula:

$$
\mathrm{N}=\frac{\text { The number of students that complete the test }}{\text { the number of students }} \times 100 \%
$$

\section{Results and Analysis}

This research and development have been produced a design of multimedia learning material line and angle. The multimedia of this research contains several things, namely; 1) Basic competencies and learning indicators to be achieved in learning to use developed multimedia learning; 2) Material learned; 3) Activity description on each page; 4) Components contained within each page; 5) Design layout of each page; 6) Flowchart.

Furthermore, the design was implemented into multimedia learning by using computer applications. Making multimedia learning software in this research using GeoGebra software as exploration media, Camtasia Studio as video and voice editing application, and Lectora Inspire as the application of layout and quiz making.

In this research has succeeded in developing multimedia learning product on the surface area of solid geometry material of Junior high school in VIII grade. When learning multimedia is started, the initial display will appear as shown in Figure 1. When students press the "Start" button a page will appear showing instructions for using this menu in this multimedia. Furthermore, students can choose the menu. There is five main menus in this multimedia, namely perception, material, and profile menu. For perception menu, there are learning objectives and learning videos that can be seen. The apperception page display is shown in Figure 2 below.

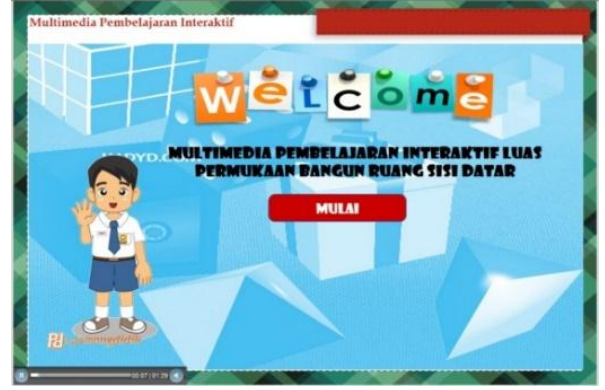

Figure 1. The initial display of multimedia

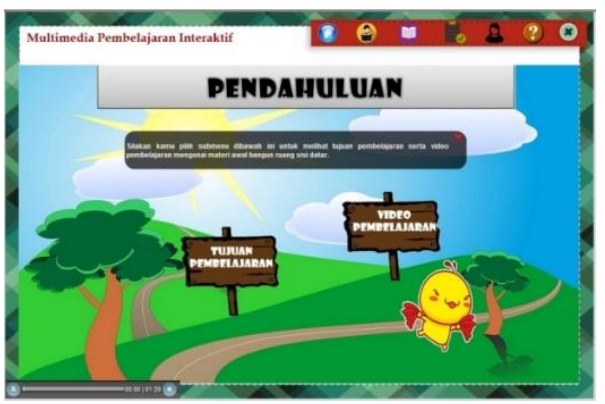

Figure 2. Apperception Menu Display

When the student selects the material menu, an initial page will display a brief description of the surface area of solid geometry, then the student learning option will be displayed. The appearance of each page can be seen in Figure 3 and 4.

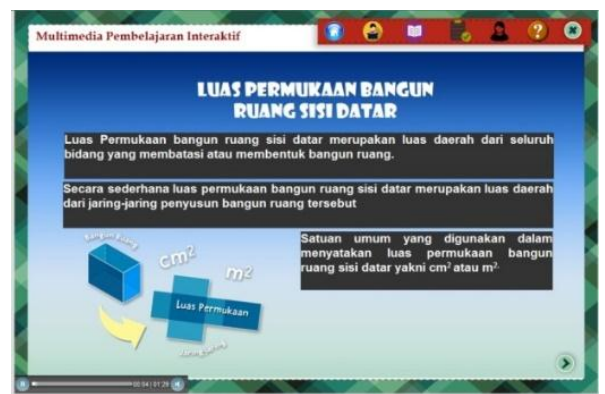

Figure 3. Start page material menu

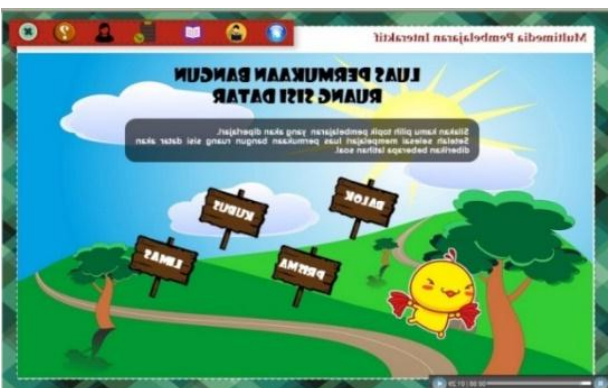

Figure 4. Display of learning topic pages

On these page students will choose the topic of learning, before proceeding to the media exploration, each topic will be given an introduction to recall the material needed. The appearance of each page can be seen in Figure 5 and 6 . 


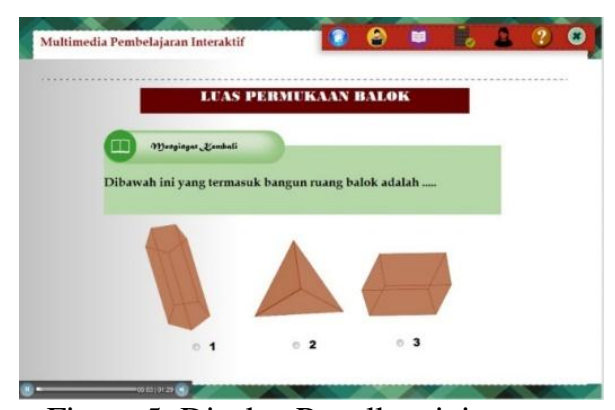

Figure 5. Display Recall activity page

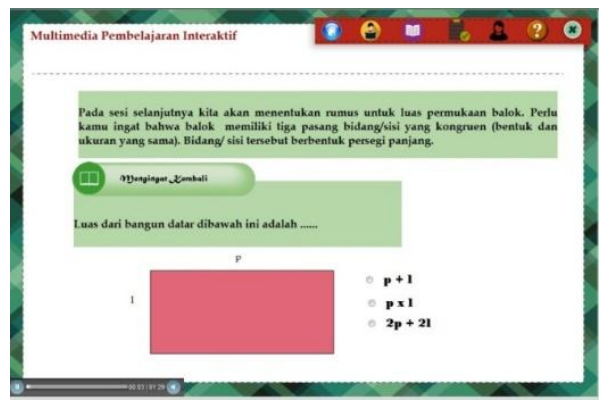

Figure 6. Display Recall activity page

Once students are able to answer the questions, students can proceed to the media exploration and conclusions, as in figure 7 and 8.

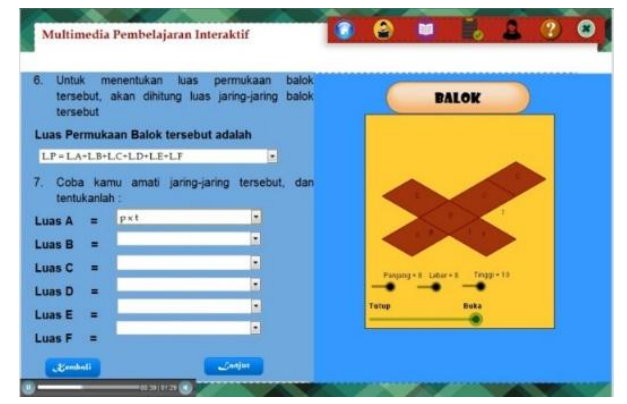

Figure 7. Media exploration

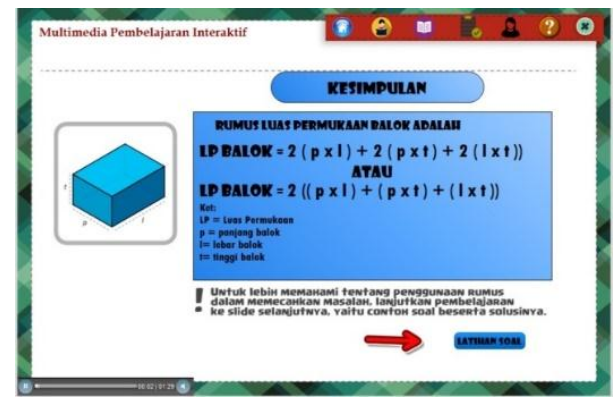

Figure 8. Conclusion page

The quality of multimedia learning products developed in this study was based on three aspects, namely, feasibility, usage, and effectiveness. The feasibility was done by a multimedia expert and material experts by using questionnaires. The summary of the results of the assessment on the multimedia learning from each expert is presented in Table 3.

Table 3

Summary of Multimedia Feasibility Test Results by Expert Material and Multimedia Expert

\begin{tabular}{lll}
\hline & Expert Material & Multimedia Expert \\
\hline Score Total Expert I & 29 & 25 \\
Score Total Expert II & 29 & 29 \\
Average Score Total & 29 & 27 \\
Criteria & Valid & Valid \\
\hline
\end{tabular}

Based on the results obtained from assessment of the learning device expert and the material learning experts, Tables 6 indicates that the developed multimedia learning belongs to the qualifying or valid criteria, as it meets the feasibility of the learning device expert and the material learning expert.

Viewed from the aspect of design presentation; Audio, animation and visual, such as back sound, sound effects, layout, typography, and the color is good and interesting. Aspects of interaction use such as operational multimedia learning and navigation are easy to operate and communicative. In general, the material presented in multimedia learning with basic competence is appropriate, contextuality is good, learning in multimedia has been systematic, logical flow, and clear, already contains sample problems, discussion, and exercise questions, subject matter can be reviewed, and The content of multimedia learning as a whole can motivate students in learning.

The use of multimedia learning developed in this study is seen from the questionnaire of students' responses to multimedia learning and interview with students that was taken on a limited trial. From the analysis results obtained that the developed multimedia learning is on the good criteria of usage.

Multimedia that had been through the limited trial process and has been revised then tested on the learning in one class for students of Class VIII in SMP Negeri 2 Kediri. From the experiment, the result shows that the mean score of teacher and student responses questionnaires are 48 and 44 respectively. So, the interactive multimedia learning a 
surface area of solid geometry including good criteria and did not need to be revised, and have valid and practical criteria.

In the dissemination, the stage was done to determine the effectiveness of the developed multimedia, but due to limited time and cost of the researchers, this stage is limited to class VIII SMP N 2 Kediri. To find out the effectiveness of the developed multimedia learning, learning was done using the multimedia in different classes and taught by different teachers with the trial class in the developing stage. The lesson was done in three meetings, the evaluation was done at the third meeting by giving the posttest about the material. A summary of the students' final grades can be seen in Table 4 .

Table 4

Summary of the student's score

\begin{tabular}{lll}
\hline No. & Variation & Data of the trial class \\
\hline 1. & The highest score & 90 \\
2. & The lowest score & 60 \\
3. & The mean of the student's score & 79 \\
4. & Number of students who complete the study & 16 \\
5. & The number of students who are not complete the study & 4 \\
6. & Classical mastery & $80 \%$ \\
\hline
\end{tabular}

The Minimum Exhaustiveness Criteria of mathematics learning in grade VIII SMP Negeri 2 Kediri is 78 . Based on Table 8 above, it can be seen that the percentage of classical completeness of students by $80 \%$. With the highest score was 90, the lowest score was 60 and the average score was 79 . Therefore, the interactive multimedia learning developed is effective in assisting learning, especially in learning mathematics.

\section{Conclusion}

Based on the results of data analysis and discussion that has been described, it can be drawn a conclusion as follows.

1) The design of multimedia learning surface area of solid geometry in this research is arranged in simple, clear, and contains several things, among others: 1) Basic competencies and learning indicators to be achieved in learning using multimedia developed; 2) items of material learned; 3) description of activities on each page; 4) the components contained in each page; 5) design the layout of each page; 6) flowchart.

2) The design of multimedia learning surface area of solid geometry material has been implemented using GeoGebra application as an exploratory media maker, Camtasia Studio application as a video editing, Lectora Inspire as a layout and quiz creation application in multimedia. So that the implementation has been done has resulted in a multimedia learning surface area of solid geometry for junior high school VIII grade, that packaged in the form of the $\mathrm{CD}$.

3) The developed learning multimedia has been tested for its effectiveness. The test results that the developed learning multimedia meets the valid, practical and effective criteria, so it is acceptable and feasible to be used as a learning media on the material surface area of solid geometry.

Teachers are encouraged to use multimedia learning developed as a supporter of computer-based learning so that the learning process is more varied. Furthermore, students are advised to use multimedia learning developed as a media to learn the material surface area of solid geometry. For other researchers interested in continuing this research, can develop multimedia in order to record the experience or learning activities of students when using multimedia, and the formation of a question bank so that questions can be randomized every time the question arises. Other interested researchers are also advised to conduct research with a wider scope or to add a material volume of solid geometry.

\section{Acknowledgements}

The author would like to thank the editor for their valuable time and advice. 


\section{References}

Iriani, D. H. (2018). The Effect of Early English Learning on Psychology. International Journal of Social Sciences and Humanities (IJSSH), 2(1), 65-74.

Mishra, S., \& Sharma, R. C. (Eds.). (2004). Interactive multimedia in education and training. Igi Global.

Newby, T., Stepich, D., Lehman, J., \& Russel, J. (2000). Instructional technology for teaching and learning. Upper Saddle River, Merrill.

Osman, S., Sahari, N., \& Zin, N. A. M. (2012). Development of interactive multimedia courseware (E-craft) for craft education. Turkish Online Journal of Distance Education, 13(4).

Sadiyani, N. W. (2018). Strategy of Improving Student Achievement in English Learning through Concentration Approach. International Journal of Physical Sciences and Engineering (IJPSE), 2(1), 47-56.

Suharsimi, A. (2009). Dasar-dasar evaluasi pendidikan. Jakarta: Bumi Aksara.

Suparsa, I. N., Mantra, I. B. N., \& Widiastuti, I. A. M. S. (2017). Developing Learning Methods of Indonesian as a Foreign Language. International Journal of Social Sciences and Humanities (IJSSH), 1(2), 51-57.

Suyanto, M. (2003). Multimedia alat untuk meningkatkan keunggulan bersaing. Penerbit Andi.

Thiagarajan, S. (1974). Instructional development for training teachers of exceptional children: A sourcebook.

Trianto, M. P. (2010). Mendesain Model Pembelajaran Inovatif-Progresif: Konsep, Landasan dan Implementasinya pada kurikulum Tingkat Satuan Pendidikan (KTSP). Jakarta: Kencana. 